\title{
Role of persistent infection in the control and severity of asthma: focus on Chlamydia pneumoniae
}

\author{
L.C. von Hertzen
}

Role of persistent infection in the control and severity of asthma: focus on Chlamydia pneumoniae. L.C.von Hertzen. C) ERS Journals Ltd 2002.

ABSTRACT: Conventional risk factors have been unable to explain most of the substantial increase in the prevalence of asthma observed in many countries during the last few decades. Much attention has been directed at the "hygiene hypothesis", the apparent inverse relationship between intense systemic childhood infections and the subsequent development of asthma and atopy. However, it is not only the absence or scarcity of infections, but the prolonged presence of certain microorganisms in the lungs that may be involved in the development of asthma.

Accumulating evidence suggests that Chlamydia pneumoniae, an intracellular ubiquitous pathogen with an innate propensity to persist and cause chronic infections, may be associated with asthma. This microorganism can achieve a state of "latency" in which it is viable but dormant and does not multiply. During this state, however, chlamydia continues to synthesize the "stress" protein, a 60-kDa heat shock protein (hsp60). This protein is able to elicit a strong host inflammatory response at sites of its production and appears to be involved in tissue injury and scarring processes.

As inflammation has been found to be present in almost all asthmatics, whatever the severity and aetiology of the disease, inhaled glucocorticoids now have an established position in the treatment of early stages. However, corticosteroids negatively affect many aspects of cell-mediated immunity and favour the shift from a T-helper-1-type response towards a T-helper-2-type response. Corticosteroids may thus severely deteriorate the host's ability to eradicate an intracellular pathogen, such as Chlamydia pneumoniae, which requires a properly functioning cell-mediated (T-helper-1-type) immune response to be cleared. These drugs are also able to reactivate persistent Chlamydia to an active growth phase, which, by increasing the production of proinflammatory cytokines at the site of infection, can further amplify inflammation in the airways of patients with asthma.

Eur Respir J 2002; 19: 546-556.
The Finnish Lung Health Association, Helsinki, Finland.

Correspondence: L.C. von Hertzen The Finnish Lung Health Association Sibeliuksenkatu 11 A1

00250 Helsinki

Finland

Fax: 358945421282

E-mail: leena.vonhertzen@filha.fi

Keywords: Asthma

Chlamydia pneumoniae

infection

persistence

control

severity

Received: November 12000

Accepted after revision June 202001
Interest in the role of infections in the subsequent development of asthma has re-emerged. Much of this interest has focused on the apparent inverse relationship between childhood infections and the later occurrence of asthma and atopy. This "hygiene hypothesis" $[1,2]$ has gained wide acceptance in the Western world as one of the most plausible explanations of the substantial increase in asthma prevalence during the last few decades. Paradoxically, this increase has coincided with the availability of better drugs and with a better understanding of many aspects of the disease [3]. However, while intense childhood infections may be protective in this respect, there is an increasing body of evidence that the prolonged presence of certain microorganisms in the bronchi may also be associated with the development of asthma. Acute viral infections are well-established triggers of asthma exacerbations among both adults and children; $\leqslant 80 \%$ of acute exacerbations may be caused by viruses [4]. By contrast, the role of chronic infections in the pathogenesis of the disease itself has remained largely obscure. Data obtained from epidemiological and animal studies suggest that the two respiratory viruses, adenovirus and respiratory syncytial virus (RSV), and the two atypical bacteria, Mycoplasma pneumoniae and Chlamydia pneumoniae, are probably able to cause persistent infections [5-10] and might be involved in the pathogenesis of asthma.

Previous articles in this Series: No. 1: von Mutius E. Infection: friend or foe in the development of atopy and asthma? The epidemiological evidence. Eur Respir J 2001; 18: 872-881. No. 2: Wennergren G, Kristjánsson S. Relationship between respiratory syncytial virus bronchiolitis and future obstructive airway diseases. Eur Respir $J$ 2001; 18: 1044-1058. No. 3: Renz H, Herz U. The bidirectional capacity of bacterial antigens to modulate allergy and asthma. Eur Respir $J$ 2002; 19: 158-171. No. 4: Schwarze J, Gelfand EW. Respiratory viral infections as promoters of allergic sensitization and asthma in animal models. Eur Respir J 2002; 19: 341-349. 
The role of RSV as a potentially causative agent of asthma has been reviewed earlier in this series [11] and will not be discussed here. Furthermore, data of the association between asthma and both adenovirus [6] and $M$. pneumoniae [10] are thus far very scanty, whereas extensive data exist for $C$. pneumoniae [12]. The focus of this review will therefore be on $C$. pneumoniae. The role of persistent $C$. pneumoniae infection in the development of asthma, and further, in the severity and control of the disease will be briefly outlined.

\section{Asthma}

Asthma, irrespective of its severity, is now recognized as a chronic inflammatory disorder of the airways [13]. The development of asthma appears to involve multiple genes that interact with each other and the environment [14]. Twin studies have found a heritability estimate ranging from $36-87 \%$ [15]. On the basis of clinical and laboratory findings, asthma has traditionally been divided into atopic (extrinsic) and nonatopic (intrinsic) subgroups [16]. The latter typically has its onset in adulthood, has a more severe clinical course than atopic asthma and is not closely associated with family history of the disease [17, 18]. Different aetiological mechanisms have been proposed to be involved in the development of these two subgroups [19], and, in particular, the aetiology of nonatopic, adult-onset asthma remains largely enigmatic.

\section{Epithelial cell injury in asthma}

Airway remodelling is a fundamental feature of asthma. Disruption and altered function of the epithelium in asthmatics have been proposed as a cause of stimuli that lead to restructuring of the airway wall, as a response to injury [20]. Inflammation and the associated healing process, which leads to scar formation and tissue remodelling, appear to be present in almost all asthmatics irrespective of disease severity, aetiology or duration of disease [21-23].

Epithelial cells in asthmatics have been found to have a reduced capacity to repair the epithelial layer following injury and an enhanced capacity to produce proinflammatory and profibrogenic cytokines [20]. Cytokines play a central role in the coordination and sustenance of the inflammation of the airways in asthma. They are not only involved in maintaining the chronic inflammatory process, but also appear to be able to initiate it [24]. In this system of complex interactions, the ultimate causes, besides genetic defects, which are responsible for the disturbance of the cytokine balance, and their relative importance, are understandably difficult to determine. However, the possible role of a persistent infection here cannot be ignored.

\section{Chlamydia pneumoniae: general features}

The Chlamydia, including the three species pathogenic to man, $C$. trachomatis, $C$. pneumoniae and
C. psittaci, are ubiquitously distributed obligate intracellular bacteria, which have no close relatives among the eubacteria [25]. Their unique developmental cycle differentiates them from all other microorganisms [26]. Chlamydia are entirely dependant on energy produced by their host [27] and replicate within the host cell cytoplasm, forming characteristic intracellular inclusions. The two distinct forms in which Chlamydia exists during its developmental cycle are well characterized; an infectious spore-like elementary body (EB) $(0.3 \mu \mathrm{m}$ in diameter $)$, and a larger noninfectious replicative reticulate body (RB). Unlike the $\mathrm{RB}$, the nonreplicative EB is adapted to survive short periods outside the host cell [28, 29]. The developmental cycle, which in vitro has been found to be completed within a couple of days, is a complex cascade of events. The biology of Chlamydia has been extensively reviewed elsewhere [30-32] and will not be reiterated here.

C. pneumoniae, previously known as C. psittaci (strain TWAR), was not discovered as a respiratory pathogen until 1985 [33], and was renamed in 1989 [34]. It is an important cause of pneumonia. During an epidemic, up to half of the pneumonia cases have been found to be caused by this organism [35]. Most infections, however, are mild or asymptomatic [36]. Reinfections are common, since the memory immunity elicited by $C$. pneumoniae appears to be short-lived and only partial [31,37]. A characteristic feature of all Chlamydia is their tendency to persist. Chronic $C$. pneumoniae infections have been associated with several important chronic diseases, in fact, many more than initially expected. Among these diseases are cardiovascular diseases, chronic obstructive pulmonary disease (COPD) and asthma [12, 38-40].

\section{Immune responses to Chlamydia pneumoniae}

C. pneumoniae elicits both humoral and cellmediated immune responses. As is generally the case with intracellular bacteria, cell-mediated immunity plays a crucial role in the resolution of chlamydial infections [41-44]. Patients with scarring sequelae of repeated/persistent $C$. trachomatis infection have been found to have a depressed cell-mediated immune response, indicated by decreased interferon (IFN)- $\gamma$ levels and increased antibody levels as compared with age- and sex-matched controls, suggesting a predominance of a T-helper (Th)-2-type immune response in these patients.

Although being largely responsible for the clearance of the organism, cell-mediated immunity may also be deleterious to the host in favouring the development of inflammation. Data from experimental and epidemiological studies of $C$. trachomatis suggest that repeated episodes of infection are required to produce the chronic inflammation associated with conjunctival scarring of trachoma, scarring and tubal obstruction in chronic salpingitis [45]. Recent studies in mice have shown that this may also be true for $C$. pneumoniae $[37,43]$. CD8 + T-cells play a crucial role in protection, whereas CD4+ T-cells have an important 
contributory role, especially in the later phases of infection $[44,46]$. In the absence of CD8+ T-cells, the infection appears to progress rapidly [46].

The role of antibodies in the protection and resolution of infection remains unclear. In an established infection, they appear to be rather ineffective, but probably have some contributory role in reinfection [47]. Nevertheless, antibodies have proven to be diagnostically important. Early discoveries concerning the associations between $C$. pneumoniae and disease have been based solely on sero-epidemiological studies. In spite of the availability of advanced gene-based techniques, serology using the microimmunofluorescence test [48], although criticized $[49,50]$, is still the principal method to diagnose C. pneumoniae infection.

\section{Persistent chlamydial infection}

As previously stated, Chlamydia have an innate propensity to persist and cause chronic infections. Such infections are insidious in that they are frequently quiescent and asymptomatic, if not harmless to the host. Irreversible tissue injury may have taken place before treatment, if any, is started. In addition, in mucosal epithelial cells, C. pneumoniae is able to grow in monocytes/macrophages, and endothelial and smooth muscle cells [51-56]. "Persistence" is defined as "a long-term association between Chlamydia and their host cells in which these organisms remain in a viable but culture-negative state" [57]. The terms "chronic" and "latent" are widely used as synonyms for persistent, although true latency in the viral sense has never been found in naturally occurring chlamydial infections [58]. Factors that lead to persistence are only partly understood, as most in vitro studies have examined the effect of IFN- $\gamma$, penicillin and nutrient, especially tryptophan, deficiency [32]. All of these factors have been shown to prevent completion of the normal developmental cycle, resulting in aberrant, noninfectious forms of Chlamydia. The effect of IFN- $\gamma$ has been found to be dose-dependant; higher doses $\left(2 \mathrm{ng} \cdot \mathrm{mL}^{-1}\right)$ completely inhibited the growth of Chlamydia in vitro, whereas with lower doses $\left(0.2 \mathrm{ng} \cdot \mathrm{mL}^{-1}\right)$ persistent infection was established. Removal of IFN- $\gamma$ resulted in infectious progeny from these aberrant forms [59].

Evidence from $C$. trachomatis infection in vitro has shown that during persistence, when Chlamydia remain viable but dormant and do not replicate [32], changed ratios of chlamydial antigens can be demonstrated; the production of $60-\mathrm{kDa}$ heat shock proteins (hsp60) is unaltered, whereas the level of the major outer membrane protein decreases markedly [59]. Since the former compound is considered an immunopathological antigen and the latter a protective antigen, alteration of their ratios may decisively affect immunopathogenesis in a persistent chlamydial infection.

Several factors associated with the host have been found to favour the establishment of a persistent C. pneumoniae infection. These factors, including male sex, advanced age, smoking, concomitant diseases, glucocorticoid usage and hereditary factors, have been reviewed previously [40]. The interaction between Chlamydia, glucocorticoids and the host's immune response will be discussed in the Chlamydia pneumoniae and the control and severity of asthma section.

\section{Immunopathological mechanisms: the role of heat shock protein 60}

Immunopathological mechanisms of chlamydial infections have been widely studied using animal models of repeated infections. These studies have clearly indicated that the basis for chlamydial diseases is immunopathological [37,45]. Multiple episodes of reinfections with $C$. trachomatis elicit some protective immunity, but the limited growth of Chlamydia induces a severe inflammation that may lead to irreversible tissue changes [45]. Consistent with this concept are the recent data obtained from $C$. pneumoniae murine models. A primary $C$. pneumoniae infection conferred a partial resistance to reinfection, but provided no protection against inflammatory changes, as an equally strong inflammatory response was observed in reinfection [37]. Even mice that are genetically predisposed to mount a Th2-type response in a primary $C$. pneumoniae infection, elicit a Th1-type response in reinfection, shown by markedly increased IFN- $\gamma$ production [43]. Only modest amounts of chlamydial antigen appear to be needed to confer immunopathological tissue destruction [45].

A single chlamydial antigen, a $57-60-\mathrm{kDa}$ protein, has been found to elicit severe inflammation when applied to the conjunctiva of guinea pigs or monkeys that have previously been infected with Chlamydia. This protein was identified as a member of the highly conserved hsp60 family of stress proteins, found both in eukaryotic and prokaryotic organisms [60]. These proteins are produced constitutively at low levels, their production being greatly enhanced in environmental stress, e.g. in an infection [61].

Convincing evidence exists of an association between immune responsiveness to chlamydial hsp60 and the severe sequelae of $C$. trachomatis infections. Elevated antibody levels to chlamydial hsp60 have been shown to be associated with scarring trachoma [62], pelvic inflammatory disease (PID) [63-65] and tubal factor infertility [66]. Recently, a role for chlamydial hsp60 in the pathogenesis of atherosclerosis has also been proposed [67, 68].

Immunopathological tissue damage appears to follow both recurrent and persistent infections, and is largely the consequence of the immune response to chlamydial hsp60 [45]. In addition, the production of proinflammatory cytokines, tumour necrosis factor (TNF)- $\alpha$, interleukin (IL)-1 $\beta$, IL-6 and IFN- $\gamma$, released by the infected cells $[43,54,56]$, and the liberation of cellular constituents from lysed cells, contribute significantly to the tissue damage and scarring processes [45]. Analogous to the mechanisms suggested to operate in persistent and recurrent $C$. trachomatis infections, the synthesis and release of chlamydial hsp60 from persistently or repeatedly infected mucosal epithelial cells or alveolar 
Table 1. - Summary of major epidemiological studies of the association between asthma and Chlamydia pneumoniae (C. pneumoniae) infection

\begin{tabular}{|c|c|c|c|c|}
\hline $\begin{array}{l}\text { [Ref. } \\
\text { no.] }\end{array}$ & $\begin{array}{l}\text { No. patients/ } \\
\text { controls }\end{array}$ & Type of study & Methods & Results \\
\hline [69] & $\begin{array}{c}61 \\
304\end{array}$ & Case-control & Serology (mIF) & $\begin{array}{l}\text { Elevated polyvalent ab levels to } C \text {. pneumoniae } \\
\text { associated with wheezing, in four cases } \\
\text { new asthma diagnosed. }\end{array}$ \\
\hline [70] & $\begin{array}{c}332 \\
98\end{array}$ & Case-control & Serology (mIF) & $\begin{array}{l}\text { Long-standing nonatopic asthma strongly } \\
\text { associated with elevated } \operatorname{IgG~ab} \\
\text { levels to } C \text {. pneumoniae. }\end{array}$ \\
\hline [71] & $\begin{array}{c}169 \\
1518\end{array}$ & Case-control & Serology (mIF) & $\begin{array}{l}\text { Elevated } \operatorname{IgG} \text { and/or IgA ab levels to } C \text {. pneumoniae } \\
\text { associated with severe chronic asthma. }\end{array}$ \\
\hline [72] & 619 & $\begin{array}{l}\text { Uncontrolled } \\
\text { cohort }\end{array}$ & Serology (mIF) & $\begin{array}{l}\text { High-dose inhaled steroids associated with } \\
\text { elevated IgG and IgA ab levels to } \\
\text { C. pneumoniae. Inverse association } \\
\text { between IgG abs and lung function. }\end{array}$ \\
\hline [9] & 108 & $\begin{array}{l}\text { Partly-controlled } \\
\text { cohort }\end{array}$ & $\begin{array}{l}\text { Secretory IgA (EIA) } \\
\text { PCR }\end{array}$ & $\begin{array}{l}\text { Elevated specific secretory IgA levels and } \\
\text { PCR positivity in subsequent samples } \\
\text { associated with multiple exacerbations. }\end{array}$ \\
\hline
\end{tabular}

mIF: microimmunofluorescence test; EIA: enzyme immunoassay; PCR: polymerase chain reaction; Ig: immunoglobulin; ab: antibody.

macrophages may provide a prolonged antigenic stimulation, which strongly amplifies chronic inflammation and ultimately leads to immunopathological tissue damage and scarring in the asthmatic lungs.

\section{Chlamydia pneumoniae and asthma}

\section{Epidemiological studies}

Accumulating evidence from sero-epidemiological studies has shown that many asthmatics have elevated antibody levels to $C$. pneumoniae, suggestive of persistent infection (table 1). HAHN et al. [69] were the first to show the association between this microorganism and adult-onset asthma. They found a strong quantitative association between the antibody level to $C$. pneumoniae and wheezing in 365 patients with respiratory illness. Elevated specific antibody levels were also significantly associated with asthmatic bronchitis after, rather than before, respiratory illness, and in some patients with $C$. pneumoniae infection, a newly diagnosed asthma was recorded. Involvement of any other microorganism, M. pneumoniae, C. trachomatis or respiratory viruses, could not be demonstrated in $96 \%$ of patients with asthmatic bronchitis or asthma [69].

A recent controlled study of 332 asthmatics provided further evidence that $C$. pneumoniae infection may be involved in the pathogenesis of asthma. Logistic regression analysis controlling for age, sex and smoking revealed that both long-standing ( $>7$ yrs since diagnosis) and recent $(<7$ yrs since diagnosis) asthma were significantly associated with elevated immunoglobulin ( $\mathrm{Ig})-\mathrm{G}$ antibody levels to C. pneumoniae (odds ratio (OR) 3.3 and 2.3, respectively). Importantly, when the atopics and nonatopics were analysed separately, an even stronger association with long-standing asthma among the nonatopics was obtained (OR 6.0). For atopic asthma, no significant associations could be found with either long-standing or recent disease [70]. In line with this study, CooK et al. [71] found in a controlled study of 169 asthmatics, that elevated $\operatorname{IgG}$ and/or IgA antibody levels to $C$. pneumoniae were significantly associated with severe chronic asthma.

Interesting data have recently been published on the association between elevated antibody levels to C. pneumoniae and severity of asthma. Specific antibody levels were measured in 619 adults with asthma, and, for those showing elevated IgG and/or IgA titres to $C$. pneumoniae, spirometry was performed and peak expiratory flow rate and symptoms were recorded twice daily for a month. This study revealed that the use of high-dose inhaled steroids was associated with a considerable increase in specific $\operatorname{IgG}(74 \%, \mathrm{p}=0.04)$ and $\operatorname{IgA}$ titres $(71 \%, \mathrm{p}=0.0001)$, as compared with the use of low-dose inhaled steroids. Further, an inverse association between IgG antibodies and forced expiratory volume in one second as a percentage of the predicted value was found in those individuals with elevated $\mathrm{IgG}$ and/or IgA titres ( $\mathrm{p}=0.04)$. Elevated IgA titres were also associated with a higher daytime symptom score $(\mathrm{p}=0.04)$. Elevated titres to $C$. pneumoniae may thus be associated with markers of asthma severity. No association between the severity of asthma and the titres to $M$. pneumoniae, adenovirus, influenza $A$ and $B$ or parainfluenza virus could be demonstrated [72].

In a cohort of 108 school-aged children with asthma symptoms, Cunningham et al. [9] showed that C. pneumoniae-specific secretory $\operatorname{IgA}$ antibodies in nasal aspirates were more than seven times higher in those children who reported at least four exacerbations during the study period of 13 months, than in those reporting only one episode $(\mathrm{p}=0.02)$. The former subgroup also tended to remain polymerase chain reaction (PCR) positive for $C$. pneumoniae, which was believed to suggest chronic infection. The immune response to suspected chronic $C$. pneumoniae infection may interact with inflammation in the bronchi 
Table 2. - Factors supporting the hypothesis that Chlamydia pneumoniae (C. pneumoniae) is involved in the pathogenesis of asthma

Supporting factors

[Ref. no.]

C. pneumoniae has an innate propensity to cause chronic infections,

which are frequently asymptomatic/subclinical.

C. pneumoniae is able to grow and multiply in mucosal epithelial cells,

monocyte/macrophages, endothelial cells and smooth muscle cells.

Epidemiological data of the association between suspected persistent infection

and asthma extensive for $C$. pneumoniae.

Severity of asthma associated with elevated antibody levels to C. pneumoniae,

not to other potential respiratory pathogens.

C. pneumoniae induces ciliostasis in the bronchi.

C. pneumoniae induces production of pro-inflammatory cytokines from infected cells.

and increase asthma symptoms. Again, this study failed to identify an important role for $M$. pneumoniae [9].

To date, data from controlled or cohort studies on the association between $C$. pneumoniae and asthma have been reported in 13 published papers and five abstracts, including $>2,000$ asthmatics overall, in addition to data from a number of smaller uncontrolled studies, case series and case reports [12]. A positive association between the markers of $C$. pneumoniae infection (one or more of: elevated serum or secretory antibody levels, positivity in the PCR test or immunohistochemistry) and asthma has been reported in all but two papers and one abstract. Studies of the relationship between asthma and $C$. pneumoniae have recently been thoroughly reviewed [12].

\section{Is the association causal or coincidental?}

As in the case of atherosclerosis [73, 74], a debate continues as to whether the association between C. pneumoniae and asthma is causal or coincidental. While data on this association are rather extensive, no conclusions can yet be drawn about cause and effect. Firstly, the available data are mostly obtained from cross-sectional studies. Prospective data from controlled studies are scanty and based on short follow-ups. Secondly, the evidence of this $C$. pneumoniae/asthma association is mainly indirect, obtained by demonstrating elevated levels of specific serum antibodies. Serology has certain limitations, particularly in suspected chronic infections [74, 75]. Data based on direct detection of the agent in the bronchial cells or alveolar macrophages are needed, even though the difficulties in diagnosing chronic C. pneumoniae infections, especially by direct methods, are well recognized [75]. Thirdly, no experimental data from animal models of asthma exist. Such data have similarly proved to be difficult to obtain since animal models of allergic sensitization and asthma, developed in sheep, monkeys and various rodents, are generally believed to mimic sensitization and acute bronchospasm rather than the chronic inflammatory process, which is the major feature in human asthma [76]. Finally, no data from large-scale intervention studies have thus far been published, although the preliminary results from the Chlamydia pneumoniae Roxithromycin Multinational (CARM) study have been presented [77]. Antibiotic trials will provide valuable additional information on the possibility that the association is causal. The antiinflammatory properties of macrolides, however, may complicate the evaluation of causality in this kind of trial.

Nevertheless, several arguments favour the hypothesis that C. pneumoniae is involved in the pathogenesis of asthma. As persistent chlamydial infections are mostly quiescent and slowly progressing, they frequently remain untreated. Severe sequelae are not uncommon. Further, C. pneumoniae is able to grow and multiply in several cell types relevant to asthma, including mucosal epithelial cells, alveolar macrophages, smooth muscle cells and endothelial cells [51-56]. In addition, data from epidemiological studies are extensive for $C$. pneumoniae as compared with other potential respiratory pathogens. Strong evidence in favour of $C$. pneumoniae is the recently reported finding, noted previously, that a significant relationship exists between the markers of asthma severity and elevated antibody levels to $C$. pneumoniae, but not to other common respiratory agents [72]. C. pneumoniae has also been found to cause ciliostasis in bronchial epithelial cells in vitro, which appears to be a specific property of $C$. pneumoniae, at least to some extent, since $C$. trachomatis had no similar effect [78]. Finally, C. pneumoniae induces pro-inflammatory cytokine synthesis in human peripheral mononuclear cells and alveolar macrophages [54, 56]. This induction of cytokine synthesis is probably not a feature specific solely to $C$. pneumoniae (table 2). Although sero-epidemiological data support the view that the role of $C$. pneumoniae in asthma is primarily in amplifying inflammation and inciting the disease process [70, 72, 79], occasional initiation of the disease by this agent cannot be ruled out. Indeed, evidence is available that this could be true of some cases $[69,70,80]$.

Could $C$. pneumoniae be a commensal in the respiratory tract without causing any harmful effects to the host? This is unlikely due to the intracellular nature of the infection and the evidence obtained from C. trachomatis infections (see the Immunopathological mechanisms; the role of heat shock protein 60 section). 


\section{Chlamydia pneumoniae and the control and severity of asthma}

Chlamydia pneumoniae and the use of glucocorticoids

The recognition of inflammations presence even in mild-to-moderate asthma [13] emphasizes the importance of early intervention with inhaled glucocorticoids, which reduce pulmonary eosinophilia and cytokine production in the lungs by effector T-cells [81]. Glucocorticoids are the most potent antiinflammatory drugs available for the treatment of asthma, and probably the only agents that will effectively control severe asthma [13]. The average doses of inhaled corticosteroids have gradually increased during the past decade. The apparent need to use higher doses of inhaled steroids in the early stage of the disease should be balanced against a range of potential adverse reactions [82]. An important, although often neglected, aspect here is the impact of glucocorticoids on Th1/Th2 balance. An increasing body of evidence from humans and animal models now exists to suggest that glucocorticoids shift the Th1/Th2 cytokine balance towards a Th2-type response [81, 83-87]. Glucocorticoids have also been proposed as the most important determinants in the micro-environment, which ultimately contributes to the development of a specific Th1/Th2 pattern [87]. The interaction between glucocorticoids and the immune system is complex and highly dependant on factors such as the stage of the target cell cycle, the activation status of the target cell and the microand macro-environment in situ [87]. This complexity evidently leads to difficulties in examining the interactions in vitro, and may largely explain the discrepant results presented [88, 89]. Further, the interaction between glucocorticosteroids and the immune system may have a genetic basis, which, in combination with secondary factors, such as infection, stress or smoking, modify glucocorticoid dynamics [87]. The major effects of glucocorticoids that are responsible for downregulation of cell-mediated immunity (Th1) and upregulation of humoral immunity (Th2) are shown in table 3. C. pneumoniae, as an intracellular parasite, requires a strong and intact cell-mediated immune response to be eradicated.

Inhibition of pro-inflammatory cytokines. In asthmatics, the production of pro-inflammatory cytokines, IL-1 $\beta$, TNF- $\alpha$, IL-6, IFN- $\gamma$ and granulocyte-macrophage colony-stimulating factor, by alveolar macrophages and bronchoalveolar leukocytes has been found to be increased [90-92]. Corticosteroid therapy inhibits the release of pro-inflammatory cytokines from human lung epithelial cells and alveolar macrophages cells in vitro [93-95]. This inhibition is evidently one of the central effects of glucocorticoids, justifying their use in asthma therapy, but leading to poor stimulation of antigen presentation and T-cells and poor activation of phagocytes [96], and thus, an impaired ability of the host to elicit innate immunity.

Inhibition of interleukin-12 production by macrophages. Inhibition of IL-12 production in macrophages/monocytes and dendritic cells is proposed to be a major mechanism by which glucocorticoids affect cytokine synthesis [86, 97]. IL-12 is the key cytokine in regulating innate and adoptive immunity. It induces IFN- $\gamma$ production and enhances cytolytic activity of CD4+ and CD8+ T-cells and natural killer (NK) cells. IL-12 is fundamental to the development of cell-mediated immunity (Th1) protective against intracellular organisms. The absence of IL-12 early in the infection results in impaired activation of innate immunity and the development of a Th2-type response with IL-4 production, which is detrimental to the control of an intracellular infection $[98,99]$. Indeed, the reduced production of IL-12 in corticosteroidtreated human macrophages has been shown to result in a decreased ability of T-cells to induce IFN- $\gamma$ and an increased ability to induce IL-4 production in vitro [81]. The effect of glucocorticoids on IL-12 synthesis appears to be direct via the inhibition of IL-12 gene transcription in macrophages [81].

Increase of interleukin-10 and transforming growth factor- $\beta$ production by monocytes/macrophages. Corticosteroids not only have immunosuppressive effects but also several stimulatory effects. For example, they stimulate the production of transforming growth factor (TGF)- $\beta$ and IL-10 by monocytes $[87,95,100]$. IL-10 is an anti-inflammatory cytokine showing a wide range of suppressing effects. It inhibits IFN- $\gamma$ production from T-cells by suppressing IL-12 production from macrophages and dendritic cells [101]. Generally, IL-10 inhibits cytokine production from Th1, NK, monocyte/ macrophage and dendritic cells, and suppresses cellmediated immunity [102]. Thus, while a glucocorticoidinduced increase in IL-10 production ameliorates the inflammation, it also severely deteriorates the host's ability to resolve an intracellular infection.

Similarly, TGF- $\beta$ is an anti-inflammatory/suppressory cytokine that shows antiproliferative activity on macrophages, endothelial cells, and T- and B-cells.

Table 3. - Major effects of glucocorticoids that dampen cell-mediated immunity and favour the establishment and further reactivation of a persistent Chlamydia pneumoniae infection

The effects of glucocorticoids

[Ref. no.]

Inhibition of pro-inflammatory cytokine synthesis by epithelial cells and macrophages

Inhibition of IL-12 synthesis by monocytes/macrophages

Increase of IL-10 and TGF- $\beta$ synthesis by macrophages

Downregulation of NK cell activity

IL: interleukin; TGF- $\beta$ : transforming growth factor- $\beta$; NK: natural killer. 
It also inhibits the induction of NK cell activities and reduces cellular expression of class II major histocompatibility complex (MHC) protein [96]. Indeed, TGF- $\beta$ and IFN- $\gamma$ have recently been shown to be reciprocally regulated $[103,104]$. A glucocorticoidinduced increase in TGF- $\beta$ level in asthmatics reduces the IFN- $\gamma$ production in NK and Th cells, further favouring the establishment of a persistent chlamydial infection [104].

Downregulation of natural killer cell activity. Corticosteroids also have a negative effect on NK cells. A decrease in NK cell activity by corticosteroids in vitro suggests a direct effect on those cells [105]. Depletion of active NK cells has been found to result in a shift from a Th1 dominant response to a more of a Th2 response in a murine model for chlamydial pneumonitis. This was considered to be due to severely impaired early IFN- $\gamma$ production in the absence of properly functioning NK cells [106]. Indeed, evidence obtained from a murine leishmaniasis indicates that differences in patterns of early responsiveness may contribute to the type of subsequent disease. The ability of the host to develop an early NK cell response may be an important feature of intracellelar infections. Chronic infection has been proposed to be related to the absence of an early effective NK cell response [107].

\section{Chlamydia pneumoniae and the severity of asthma}

In the large, controlled study of asthmatics referred to earlier, BLACK et al. [72] found that elevated antibody levels to $C$. pneumoniae were independently associated with the markers of asthma severity, including lung function and symptom scores. This finding cannot be explained by an unspecific polyclonal antibody response, which might be expected in individuals with advanced disease, and a strongly polarized Th2-type immune response as a result of high doses of glucocorticoid usage [81, 83-87], since no association was found between the severity of asthma and elevated titres to other common respiratory pathogens [72]. The other recent controlled study of asthmatics with long-standing or recently diagnosed disease revealed that the association between elevated antibody levels to $C$. pneumoniae and the disease, after controlling for potential confounding factors, was strongest for nonatopic long-standing asthma and much weaker, although also significant, for nonatopic recent asthma [70]. Further evidence has been obtained from a cohort of asthmatics categorized as having mild, moderate or severe disease. Regression analysis showed the strongest association between elevated antibody levels to $C$. pneumoniae and the patients with moderate-to-severe disease. By contrast, no significant association could be found between elevated antibody levels to $C$. pneumoniae and mild asthma [79], which, again, does not lend support to the view that $C$. pneumoniae is primarily involved in the initiation of asthma.

Cytokine patterns may change along with the progression of the disease. In tuberculosis there are differences in the cytokine patterns according to the amount of lung involvement, suggesting a role for these mediators in the immunopathogenesis related to the distinct clinical forms of pulmonary tuberculosis, i.e. a predominantly Th1- or Th2-type response in mild or progressive disease, respectively [108]. Treatment may restore the biased Th1/Th2 balance [109]. Whether a similar shift also occurs in long-term infections caused by $C$. pneumoniae is unknown, and, in addition, data are unavailable on asthma showing changes in the cytokine pattern according to the severity of the disease [24]. However, as glucocorticoids favour the development of a Th2-type response $[81,86,87]$, a strongly polarized $\mathrm{Th} 2$ response would be expected in advanced stages of the disease.

The interaction of $C$. pneumoniae, glucocorticoids and the host's immune system in asthma may lead to a vicious circle, where the escalating doses of glucocorticoids drive the Th1/Th2 balance towards a strongly polarized Th2-type response and trigger the re-activation of persistent Chlamydia to actively growing forms $[32,110,111]$. Persistent and recurrent chlamydial infections may lead to severe inflammation, fibrosis and, finally, tissue scarring [62, 112], and may significantly accelerate disease progression in asthmatics. Higher doses of glucocorticoids, not only inhaled but also systemic, are then needed to control the continuously aggravated inflammation in the bronchi. A hypothetical model of this interaction is presented in figure 1.

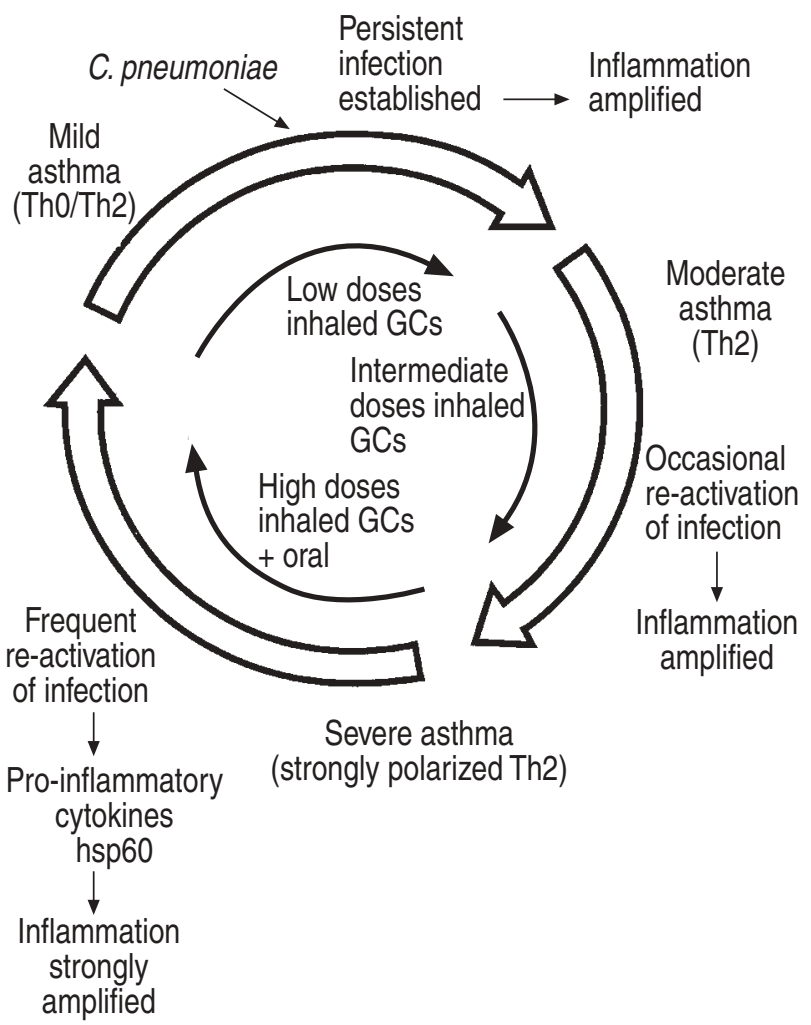

Fig. 1. - Hypothetical model of the interaction between Chylamydia pneumoniae (C. pneumoniae) corticosteroids and the host's immune system in asthma. Outer circle indicates stages of asthma and the inner circle doses of glucocorticoids (GCs). Th: T-helper (cell); hsp60: $60-\mathrm{kDa}$ heat shock protein. 


\section{Conclusion}

Elevated titres to Chlamydia pneumoniae, but not to other potential respiratory pathogens, have been found to be associated with markers of asthma severity. The relationship between elevated titres to Chlamydia pneumoniae and asthma has also been shown to be stronger for long-standing than recent asthma. Both pieces of evidence suggest that Chlamydia pneumoniae is primarily an inciter of inflammation rather than an initiator of the disease, although the latter possibility cannot be wholly ruled out. Whether antibiotic treatment will be beneficial in limiting disease progression in the future, remains to be seen. As yet, no guidelines for the treatment of persistent Chlamydia pneumoniae infections are available.

\section{References}

1. Strachan DP. Is allergic disease programmed in early life? Clin Exp Allergy 1994; 24: 603-605.

2. Romagnani S. Regulation of the development of type 2 helper cells in allergy. Curr Opin Immunol 1994; 6: 838-846.

3. Frew A. Introduction. Clin Asthma Rev 1997; 1.

4. Johnston SL, Pattemore PK, Sanderson G, et al. Community study of role of viral infections in exacerbations of asthma in 9-11 year old children. BMJ 1995; 310: 1225-1228.

5. Matsuse T, Hayashi S, Kuwano K, Keunecke H, Jefferies WA, Hogg JC. Latent adenoviral infection in the pathogenesis of chronic airway obstruction. Am Rev Respir Dis 1992; 148: 177-184.

6. Macek V, Sorli J, Kopriva S, Marin J. Persistent adenoviral infection and chronic airway obstruction in children. Am J Respir Crit Care Med 1994; 150: 7-10.

7. Bramley AM, Vitalis TZ, Wiggs BR, Hegele RG. Effects of respiratory syncytial virus persistence on airway responsiveness and inflammation in guineapigs. Eur Respir J 1999; 14: 1061-1067.

8. Dakhama A, Vitalis TZ, Hegele RG. Persistence of respiratory syncytial virus (RSV) infection and development of RSV-specific IgG1 response in a guinea-pig model of acute bronchiolitis. Eur Respir J 1997; 10: 20-26.

9. Cunningham AF, Johnston SL, Julious SA, Lampe FC, Ward ME. Chronic Chlamydia pneumoniae infection and asthma exacerbations in children. Eur Respir J 1998; 11: 345-349.

10. Kraft M, Cassell GH, Henson JE, et al. Detection of Mycoplasma pneumoniae in the airways of adults with chronic asthma. Am J Respir Crit Care Med 1998; 158: 998-1001.

11. Wennergren G, Kristjánsson S. Relationship between respiratory syncytial virus bronchiolitis and future obstructive airways diseases. Eur Respir $J$ 2000; 13: $1044-1058$

12. Hahn DL. Chlamydia pneumoniae, asthma, and COPD: what is the evidence? Ann Allergy Asthma Immunol 1999; 83: 271-288, 291.

13. Lemanske RF, Busse WW. Asthma. JAMA 1997; 278: 1855-1873.

14. Bleecker ER, Postma DS, Meyers DA. Evidence for multiple genetic susceptibility loci for asthma. Am J Respir Crit Care Med 1997; 156: S113-S116.
15. Barnes KC. Gene-environment and gene-gene interaction studies in the molecular genetic analysis of asthma and atopy. Clin Exp Allergy 1999; 29: Suppl. 4, 47-51.

16. Rackeman FM. A working classification of asthma. Am J Med 1947; 3: 601-606.

17. Kroegel C, Jäger L, Walker C. Is there place for intrinsic asthma as a distinct immunopathological entity? Eur Respir J 1997; 10: 513-515.

18. Walker C, Bode E, Boer L, Hansel TT, Blaser K, Virchow JC Jr. Allergic and nonallergic asthmatics have distinct patterns of T-cell activation and cytokine production in peripheral blood and bronchoalveolar lavage. Am Rev Respir Dis 1992; 146: 109-115.

19. Corrigan CI, Kay AB. T cells and eosinophils in the pathogenesis of asthma. Immunol Today 1992; 13: 501-507.

20. Holgate ST, Lackie PM, Davies DE, Roche WR, Walls AF. The bronchial epithelium as a key regulator of airway inflammation and remodelling in asthma. Clin Exp Allergy 1999; 29: Suppl. 2, 90-95.

21. Bousquet J, Chanez P, Lacoste JY, et al. Asthma: a disease remodeling the airways. Allergy 1992; 47: 3-11.

22. Haahtela T. Airway remodelling takes place in asthma - what are the clinical implications? Clin Exp Allergy 1997; 27: 351-353.

23. Chetta A, Foresi A, Del Donno M, Bertorelli G, Pesci A, Olivieri D. Airways remodeling is a distinctive feature of asthma and is related to severity of disease. Chest 1997; 111: 852-857.

24. Chung KF, Barnes PJ. Cytokines in asthma. Thorax 1999; 54: 825-857.

25. Weisburg WG, Hatch TP, Woese CR. Eubacterial origin of Chlamydiae. J Bacteriol 1986; 167: 570-574.

26. Moulder JW, Hatch TP, Kuo CC, Schachter J, Storz J. Genus Chlamydia. In: Kieg NR, Holt J, eds. Bergey's Manual of Systematic Bacteriology, vol 1. Baltimore, The Williams and Wilkins Co., 1984; pp. $729-739$.

27. Hatch TP. Metabolism of Chlamydia. In: Barron AL, ed. Microbiology of Chlamydia. Florida, CRC Press Inc., 1988; pp. 98-109.

28. Theunissen HJ, Lemmens-den Toom NA, Burggraaf A, Stolz E, Michel MF. Influence of temperature and relative humidity on the survival of Chlamydia pneumoniae in aerosols. Appl Environ Microbiol 1993; 59: 2589-2593.

29. Falsey AR, Walsh EE. Transmission of Chlamydia pneumoniae. J Infect Dis 1993; 168: 493-496.

30. Kuo CC, Jackson LA, Campbell LA, Grayston JT. Chlamydia pneumoniae (TWAR). Clin Microbiol Rev 1995; 8: 451-461.

31. Ward ME. The immunobiology and immunopathology of chlamydial infections. APMIS 1995; 103: 769796.

32. Beatty WL, Morrison RP, Byrne G. Persistent Chlamydiae: from cell culture to a paradigm for chlamydial pathogenesis. Microbiol Rev 1994; 58: 686-699.

33. Saikku P, Wang SP, Kleemola M, Brander E, Rusanen E, Grayston JT. An epidemic of mild pneumonia due to an unusual strain of Chlamydia psittaci. J Infect Dis 1985; 151: 832-839.

34. Grayston JT, Kuo CC, Campbell LA, Wang SP. Chlamydia pneumoniae sp. nov. for Chlamydia sp. strain TWAR. Int J Syst Bacteriol 1989; 39: 88-90.

35. Ekman MR, Grayston JT, Visakorpi R, Kleemola M, 
Kuo CC, Saikku P. An epidemic of infections due to Chlamydia pneumoniae in military conscripts. Clin Infect Dis 1993; 17: 420-425.

36. Kuo CC, Campbell LA. Is infection with Chlamydia pneumoniae a causative agent in atherosclerosis? $\mathrm{Mol}$ Med Today 1998; 4: 426-430.

37. Kaukoranta-Tolvanen SS, Laurila A, Saikku P, Leinonen M, Laitinen K. Experimental Chlamydia pneumoniae infection in mice: Effect of reinfection and passive immunization. Microb Pathog 1995; 18: 279-288.

38. Gibbs RGJ, Carey N, Davies AH. Chlamydia pneumoniae and vascular disease. Br J Surgery 1998; 85: 1191-1197.

39. Danesh J, Collins R, Peto R. Chronic infections and coronary heart disease: is there a link? Lancet 1997; 350: $430-436$

40. von Hertzen LC. Chlamydia pneumoniae and its role in chronic obstructive pulmonary disease. Ann Med 1998; 30: 27-37.

41. Holland MJ, Bailey RL, Hayes LJ, Whittle HC, Mabey DC. Conjunctival scarring in trachoma is associated with depressed cell-mediated immune response to chlamydial antigens. J Infect Dis 1993; 168: 1528-1531.

42. Bailey RL, Holland MJ, Whittle HC, Mabey DC. Subjects recovering from human ocular chlamydial infection have enhanced lymphoproliferative response to chlamydial antigens compared with those of persistently diseased controls. Infect Immun 1995; 63: 389-392.

43. Penttilä J, Anttila M, Puolakkainen M, et al. Local immune responses to Chlamydia pneumoniae in the lungs of $\mathrm{BALB} / \mathrm{c}$ mice during primary infection and reinfection. Infect Immun 1998; 66: 5113-5118.

44. Rottenberg ME, Rothfuchs ACG, Gigliotti D, Svanholm C, Bandholtz L, Wigzell H. Role of innate and adaptive immunity in the outcome of primary infection with Chlamydia pneumoniae, as analyzed in genetically modified mice. J Immunol 1999; 162: 2829 2836.

45. Morrison RP. Chlamydial hsp60 and the immunopathogenesis of chlamydial disease. Semin Immunol 1991; 3: 25-33.

46. Svanholm C, Bandholtz L, Castanos-Velez E, Wigzell H. Protective DNA immunization against Chlamydia pneumoniae. Scand J Immunol 2000; 51: 345-353.

47. Ward ME. An update on the immunology of chlamydial infection. In: Stary A, ed. Proceedings of the 3rd Meeting of the European Society for Chlamydia Research. Bologna, Societa Editrice Esculapio, 1996; pp. 58-62.

48. Wang SP, Grayston TJ. Microimmunofluorescence serological studies with the TWAR organism. In: Oriel JD, Ridgway G, Schachter J, Taylor-Robinson D, Ward M, eds. Chlamydial infections. Cambridge, Cambridge University Press, 1986: 329-332.

49. Kern DG, Neill MA, Schachter J. A seroepidemiologic study of Chlamydia pneumoniae in Rhode Island. Evidence of serologic cross-reactivity. Chest 1993; 104: 208-213.

50. Ozanne G, Lefebvre J. Specificity of the microimmunofluorescence assay for the serodiagnosis of Chlamydia pneumoniae infections. Can J Microbiol 1992; 38: 1185-1189.

51. Yang Z, Cummings PK, Patton DL, Kuo C. Ultrastructural lung pathology of experimental Chlamydia pneumoniae pneumonitis in mice. J Infect Dis 1994; 170: $464-467$.

52. Gaydos GA, Summersgill JT, Sahany NN, Ramirez JA, Quinn TC. Replication of Chlamydia pneumoniae in vitro in human macrophages, endothelial cells, and aortic artery smooth muscle cells. Infect Immun 1996; 64: 1614-1620.

53. Kaukoranta-Tolvanen SS, Laitinen K, Saikku P, Leinonen M. Chlamydia pneumoniae multiplies in human endothelial cells in vitro. Microb Pathog 1994; 16: 313-319.

54. Kaukoranta-Tolvanen SS, Teppo AM, Laitinen K, Saikku P, Linnavuori K, Leinonen M. Growth of Chlamydia pneumoniae in cultured human peripheral blood mononuclear cells and induction of a cytokine response. Microb Pathog 1996; 21: 215-221.

55. Airenne S, Surcel HM, Alakärppä H, et al. Chlamydia pneumoniae infection in human monocytes. Infect Immun 1999; 67: 1445-1449.

56. Redecke V, Dalhoff K, Bohnet S, Braun J, Maass M. Interaction of Chlamydia pneumoniae and human alveolar macrophages: infection and inflammatory response. Am J Respir Cell Mol Biol 1998; 19: 721727.

57. Morrison RP. Persistent Chlamydia trachomatis infection: in vitro phenomenon or in vivo trigger of reactive arthritis? J Rheumatol 1998; 25: 610-612.

58. Schachter J. Diagnosis of chronic chlamydial infection. In: Spencer RC, Wright EP, Newsom SW, eds. Rapid methods and automation in microbiology and immunology. Hampshire, Intercept Ltd, 1994; pp. 373-380.

59. Beatty WL, Byrne G, Morrison RP. Morphologic and antigenic characterization of interferon $\gamma$-mediated persistent Chlamydia trachomatis infection in vitro. Proc Natl Acad Sci USA 1993; 90: 3998-4002.

60. Morrison RP, Belland RJ, Lyng K, Caldwell HD. Chlamydial disease pathogenesis. The $57-\mathrm{kDa}$ chlamydial hypersensitivity antigen is a stress response protein. J Exp Med 1989; 170: 1271-1283.

61. Young RA, Elliott TJ. Stress proteins, infection and immune surveillance. Cell 1989; 59: 5-8.

62. Peeling RW, Bailey RL, Conway DJ, et al. Antibody response to the $60-\mathrm{kDa}$ chlamydial heat-shock protein is associated with scarring trachoma. J Infect Dis 1998; 177: 256-259.

63. Peeling RW, Kimani J, Plummer F, et al. Antibody to chlamydial hsp60 predicts an increased risk for chlamydial pelvic inflammatory disease. $J$ Infect Dis 1997; 175: 1153-1158.

64. Domeika M, Domeika K, Paavonen J, Mårdh PA, Witkin SS. Humoral immune response to conserved epitopes of Chlamydia trachomatis and human $60-\mathrm{kDa}$ heat-shock protein in women with pelvic inflammatory disease. J Infect Dis 1998; 177: 714-719.

65. Eckert LO, Hawes SE, Wölner-Hanssen P, et al. Prevalence and correlates of antibody to chlamydial heat shock protein in women attending sexually transmitted disease clinics and women with confirmed pelvic inflammatory disease. J Infect Dis 1997; 175: 1453-1458.

66. Toye BB, Laferriere C, Claman P, Jessamine P, Peeling R. Association between antibody to the chlamydial heat-shock protein and tubal infertility. J Infect Dis 1993; 168: 1236-1240.

67. Kol A, Sukhova GK, Lichtman AH, Libby P. Chlamydial heat shock protein 60 localizes in human 
atheroma and regulates macrophage tumor necrosis factor- $\alpha$ and matrix metalloproteinase expression. Circulation 1998; 98: 300-307.

68. Mayr M, Metzler B, Kiechl S, et al. Endothelial cytotoxicity mediated by serum antibodies to heat shock proteins of Escherichia coli and Chlamydia pneumoniae. Circulation 1999; 99: 1560-1566.

69. Hahn DL, Dodge R, Golubjatnikov R. Association of Chlamydia pneumoniae (strain TWAR) infection with wheezing, asthmatic bronchitis and adult onset asthma. JAMA 1991; 266: 225-230.

70. von Hertzen L, Töyrylä M, Gimishanov A, et al. Asthma, atopy and Chlamydia pneumoniae antibodies in adults. Clin Exp Allergy 1999; 29: 522-528.

71. Cook PJ, Davies P, Tunnicliffe W, Ayres JG, Honeybourne D, Wise R. Chlamydia pneumoniae and asthma. Thorax 1998; 53: 254-259.

72. Black PN, Scicchitano R, Jenkins CR, et al. Serological evidence of infection with Chlamydia pneumoniae is related to the severity of asthma. Eur Respir $J$ 2000; 15: 254-259.

73. Jackson LA, Campbell LA, Schmidt RA, et al. Specificity of detection of Chlamydia pneumoniae in cardiovascular atheroma. Am J Pathol 1997; 150: $1785-1790$.

74. Grayston TJ. Chlamydia pneumoniae (TWAR) and coronary heart disease: from hypothesis to treatment. In: Saikku P, ed. Proceedings of the 4th Meeting for the European Society for Chlamydia Research. Bologna, Societa Editrice Esculapio, 2000; pp. 380383.

75. Saikku P. Diagnosis of acute and chronic Chlamydia pneumoniae infections. In: Orfila J, Byrne GI, Chernesky MA, et al., eds. Chlamydial infections. Bologna, Societa Editrice Esculapio, 1994; pp. 163 172.

76. Frew AJ. Are models of asthma useful in evaluating anti-asthma drugs? Clin Asthma Rev 1997; 1: 23-31.

77. Black P, Jenkins C, Blasi F, Allegra L, Scicchitano R, Mills G. Chlamydia pneumoniae Asthma Roxithromycin Multinational (CARM) study. Eur Respir $J$ 1999; 14: Suppl. 30, 289s.

78. Shemer-Avni Y, Lieberman D. Chlamydia pneumoniaeinduced ciliostasis in ciliated bronchial epithelial cells. J Infect Dis 1995; 171: 1274-1278.

79. von Hertzen L, Vasankari T, Liippo K, Wahlström E, Puolakkainen M. Chlamydia pneumoniae and severity of asthma. Scand J Infect Dis 2002 (in press).

80. Hahn DL, McDonald R. Can acute Chlamydia pneumoniae respiratory tract infection initiate chronic asthma? Ann Allergy Asthma Immunol 1998; 81: 339344.

81. Blotta MH, DeKruyff RH, Umetsu DT. Corticosteroids inhibit IL-12 production in human monocytes and enhance their capacity to induce IL-4 synthesis in CD4+ lymphocytes. J Immunol 1997; 158: 5589-5595.

82. Wilson JW. High-dose inhaled steroids in mild to moderate asthma: the pros and cons. Clin Asthma Rev 1997; 1: 33-38.

83. Daynes RA, Araneo BA. Contrasting effects of glucocorticoids on the capacity of $\mathrm{T}$ cells to produce the growth factors interleukin 2 and interleukin 4. Eur J Immunol 1989; 19: 2319-2325.

84. Norbiato $G$, Bevilacqua $M$, Vago $T$, Clerici $M$. Glucocorticoids and Th1, Th2 type cytokines in rheumatoid arthritis, osteoarthritis, asthma, atopic dermatitis and AIDS. Clin Exp Rheumatol 1997; 15: 315-323.

85. Ramirez F, Fowell DJ, Puklavec M, Simmonds S, Mason D. Glucocorticoids promote a Th2 cytokine response by CD4+ T cells in vitro. J Immunol 1996; 156: 2406-2412.

86. DeKruyff RH, Fang Y, Umetsu DT. Corticosteroids enhance the capacity of macrophages to induce Th2 cytokine synthesis in CD4+ lymphocytes by inhibiting IL-12 production. J Immunol 1998; 160: 2231-2237.

87. Wilckens T, De Rijk R. Glucocorticoids and immune function: unknown dimensions and new frontiers. Immunol Today 1997; 18: 418-424.

88. Wu CY, Fargeas C, Nakajima T, Delespesse G. Glucocorticoids suppress the production of interleukin 4 by human lymphocytes. Eur $J$ Immunol 1991; 21: 2645-2647.

89. Umland SP, Nahrebne DK, Razac S, et al. The inhibitory effects of topically active glucocorticoids on IL-4, IL- 5 and interferon- $\gamma$ production by cultured primary CD4+ T cells. J Allergy Clin Immunol 1997; 100: 511-519.

90. Spiteri MA, Prior C, Herold M, Knight RA, Clarke SW, Chung KF. Spontaneous release of IL-1, IL-6, TNF $\alpha$ and GMCSF by alveolar macrophages (AM) in bronchial asthma. Am Rev Respir Dis 1992; 145: A239.

91. Hallsworth MP, Soh CP, Lane SJ, Arm JP, Lee TH. Selective enhancement of GM-CSF, TNF $\alpha$, IL-1 $\beta$ and IL- 8 production by monocytes and macrophages of asthmatic subjects. Eur Respir J 1994; 7: 1096-1102.

92. Cembrzynska-Norvak M, Szklarz E, Inglot AD, Teodorczyk-Injeyan JA. Elevated release of TNF $\alpha$ and interferon-gamma by bronchalveolar leukocytes from patients with bronchial asthma. Am Rev Respir Dis 1993; 147: 291-295.

93. Ek A, Larsson K, Siljerud S, Palmberg L. Fluticasone and budesonide inhibit cytokine release in human lung epithelial cells and alveolar marcrophages. Allergy 1999; 54: 691-699.

94. John M, Lim S, Seybold J, et al. Inhaled corticosteroids increase interleukin-10 but reduce macrophage inflammatory protein- $1 \alpha$, granulocyte-macrophage colonystimulating factor, and interferon- $\gamma$ release from alveolar macrophages in asthma. Am J Respir Crit Care Med 1998; 157: 256-262.

95. Hodge G, Flower R, Han P. Methyl-prednisolone up-regulates monocyte interleukin-10 production in stimulated whole blood. Scand J Immunol 1999; 49: $548-553$.

96. Oppenheim JJ, Ruscetti FW, Faltynek C. Cytokines. In: Stites DP, Terr AI, Parslow TG, eds. Basic and Clinical Immunology. East Norwalk, Appleton \& Lange, 1994; pp. 105-123.

97. Larsson S, Linden M. Effects of a corticosteroid, budesonide, on production of bioactive IL-12 by human monocytes. Cytokine 1998; 10: 786-789.

98. Trinchieri G. Interleukin 12: a pro-inflammatory cytokine with immunoregulatory functions that bridge innate resistance and antigen-specific adaptive immunity. Annu Rev Immunol 1995; 13: 251-276.

99. Flynn JL, Bloom BR. Role of T1 and T2 cytokines in the response to Mycobacterium tuberculosis. Ann NY Acad Sci 1996; 795: 137-146.

100. Matthias J, Lim S, Seybold J, et al. Inhaled corticosteroids increase interleukin-10 but reduce macrophage 
inflammatory protein- $1 \alpha$, granulocyte-macrophage colony-stimulating factor, and interferon- $\gamma$ release from alveolar macrophages in asthma. Am J Respir Crit Care Med 1998; 157: 256-262.

101. D'Andrea A, Aste-Amezaga M, Valiante NM, Ma X, Kubin M, Trinchieri G. Interleukin-10 (IL-10) inhibits human lymphocyte interferon-gamma production by suppressing natural killer cell stimulatory factor/IL-12 synthesis in accessory cells. J Exp Med 1993; 178: 1041-1048.

102. Moore KW, $\mathrm{O}^{\prime}$ Garra A, de Waal Malefyt R, Vieira P, Mosmann TR. Interleukin-10. Annu Rev Immunol 1993; 11: 165-190.

103. Strober W, Kelsall B, Fuss I, et al. Reciprocal IFN $\gamma$ and TGF $\beta$ responses regulate the occurrence of mucosal inflammation. Immunol Today 1997; 18: 6164.

104. Wilkinson KA, Aung H, Wu M, Toossi Z. Modulation of transforming growth factor $\beta-1$ gene expression by interleukin-12. Scand J Immunol 2000; 52: 271-277.

105. Bateman A, Singh A, Kral T, Solomon S. The immune-hypothalamic-pituitary-adrenal axis. Endocrine Rev 1989; 10: 92-112.

106. Tseng CTK, Rank RG. Role of NK cells in early host cell response to chlamydial genital infection. Infect Immun 1998; 66: 5867-5875.
107. Scott P, Scharton T. Interaction between the innate and the acquired immune system following infection of different mouse strains with Leishmania major. Ann NY Acad Sci 1994; 730: 84-92.

108. Dlugovitzky D, Bay ML, Rateni L, et al. In vitro synthesis of interferon- $\gamma$, interleukin-4, trans-forming growth factor- $\beta$ and interleukin- $1 \beta$ by peripheral blood mononuclear cells from tuberculosis patients: relationship with the severity of pulmonary involvement. Scand J Immunol 1999; 49: 210-217.

109. Dieli F, Singh M, Spallek R, et al. Change of Th0 to Th1 cell-cytokine profile following tuberculosis chemotherapy. Scand J Immunol 2000; 52: 96-102.

110. Malinverni R, Kuo CC, Campbell LA, Grayston JT. Reactivation of Chlamydia pneumoniae lung infection in mice by cortisone. J Infect Dis 1995; 172: 593-594.

111. Laitinen K, Laurila AL, Leinonen M, Saikku P. Reactivation of Chlamydia pneumoniae infection in mice by cortisone treatment. Infect Immun 1996; 64: $1488-1490$.

112. van Voorhis WC, Barrett LK, Cosgrove Sweeney YT, Kuo CC, Patton DL. Repeated Chlamydia trachomatis infection in Macaca nemestrina fallopian tubes produces a Th1-like cytokine response associated with fibrosis and scarring. Infect Immun 1997; 65: 21752182. 